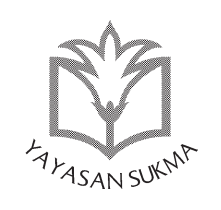

SUKMA: JURNAL PENDIDIKAN

ISSN: 2548-5105 (p), 2597-9590 (e)

Volume 2 Issue 2, Jul-Dec 2018, pp. 223-245

https://doi.org/10.32533/02204.2018

www.jurnalsukma.org

\title{
KAUM MUDA, PENDIDIKAN AGAMA DAN GLOBALISASI \\ Pendidikan Agama Islam dan Budi Pekerti yang Inklusif dan Toleran
}

\section{Stepanus Sigit Pranoto}

UIN Sunan Kalijaga Yogyakarta, Indonesia

email: sspranoto86@gmail.com

\section{Abstract}

Dealing with radical understandings in religion, religious education in schools is an alternative to counteracting it. Lack of true religious knowledge, lack of social awareness and low levels of parental supervision and mentoring are thought to be a factor in increasing radical understanding, especially among young people. Therefore religious education in schools needs to be directed to take part in overcoming it by providing inclusive and tolerant material for students. This research aims to see how the government strives for 
an inclusive and tolerant model of religious education. $B y$ reading and analyzing the material in the book Pendidikan Agama Islam dan Budi Pekerti for elementary and secondary schools, this study shows that the government has attempted to provide inclusive and tolerant religious education.

[Berhadapan dengan paham-paham radikal dalam beragama, pendidikan agama di sekolah menjadi satu alternatifbagi upaya menangkalnya. Kurangnya pengetahuan agama yang benar, kurangnya kesadaran sosial dan rendahnya tingkat pengawasan dan pendampingan orangtua diduga menjadi faktor meningkatnya paham radikal, khususnya di kalangan kaum muda. Oleh karena itu pendidikan agama di sekolah perlu diarahkan untuk turut serta mengatasinya dengan memberikan materi yang inklusif dan toleran bagi para siswa. Penelitian ini hendak melihat bagaimana pemerintah mengupayakan model pendidikan agama yang inklusif dan toleran. Dengan membaca dan menganalisa materi-materi yang ada dalam buku Pendidikan Agama Islam dan Budi Pekerti untuk sekolah dasar dan menengah, penelitian ini memperlihatkan bahwa pemerintah telah berupaya memberikan pendidikan agama yang inklusif dan toleran.]

Keywords: radicalism, islamic religious education, inclusive and tolerant education, youth, globalization

\section{A. Pendahuluan}

Keprihatinan yang dihadapi masyarakat Indonesia saat ini adalah menguatnya paham-paham radikal dalam beragama. Radikalisme agama menjadi musuh bersama dalam kehidupan plural atau majemuk seperti di Indonesia. Survey yang dilakukan oleh Badan Intelijen Negara (BIN) mengungkap bahwa sekitar $39 \%$ mahasiswa dari sejumlah perguruan tinggi telah terpapar 
paham radikal (Tempo 2018). Penelitian yang sama juga memperlihatkan bahwa $24 \%$ mahasiswa dan $23,3 \%$ pelajar SMA yang disurvey setuju dengan jihad demi tegaknya negara Islam. Sebagai negara majemuk, fakta tersebut merupakan sebuah tantangan yang harus dihadapi dan disikapi dengan serius. Apalagi beragam peristiwa intoleransi semakin sering terjadi, di mana para pelaku tindakan intoleran seringkali mengatasnamakan agama yang mereka anut.

Situasi seperti ini mengundang pertanyaan besar: Dari mana paham radikal tersebut diperoleh? Memang tak bisa dipungkiri bahwa di era global saat ini beragam informasi, termasuk bermacam paham radikal, dengan mudah bisa diperoleh. Generasi muda yang saat ini sedang mengenyam pendidikan menengah dan tinggi sebagian besar adalah para pengguna internet. Mereka bisa dengan mudah mengakses beragam informasi melalui internet dan media sosial.

Penulis menduga minimnya pengetahuan agama yang benar, kurangnya kesadaran sosial dan rendahnya tingkat pengawasan serta pendampingan dari orangtua menjadi aspek meningkatnya paham radikalisme di kalangan kaum muda. Maka upaya pencegahan semakin besarnya paham radikalisme perlu dilakukan melalui ketiga aspek tersebut: peningkatan pengetahuan agama, peningkatan kesadaran sosial, dan peningkatan pengawasan serta pendampingan.

Pendidikan agama di sekolah menjadi salah satu sarana dalam upaya pencegahan paham radikalisme tersebut. Namun, dari pernyataan ini akan muncul pula pertanyaan di seputar peran pendidikan agama di Indonesia yang telah diberikan selama ini. Di Indonesia, Pendidikan Agama sebenarnya sudah menjadi bagian dari kurikulum pendidikan di Indonesia sejak kepemimpinan Menteri Agama ke-2, Prof. K.H. Fathurrahman Kafrawi (1946-1947). Saat itu dikeluarkan peraturan bersama antara Menteri Agama dengan Menteri PPK (Pendidikan, Pengajaran, dan Kebudayaan) No. 1142/BHG A dan No. 1285/kj9 mengenai: 1) Perlunya agama menjadi salah satu pelajaran yang 
diberikan di Sekolah Rakyat (SR); 2) Guru Agama disediakan oleh pihak kementrian dan dibayar oleh pemerintah; 3) Guru Agama harus mempunyai pengetahuan umum dan untuk maksud tersebut didirikan sekolah Pendidikan Guru Agama (PGA); dan 4) Pesantren dan Madrasah harus dipertinggi mutunya (Tholkhah 2009, 112). Dan di era-era berikutnya, Pendidikan Agama secara formal juga terus diberikan di sekolah. Maka pertanyaan yang muncul adalah: Ada apa dengan Pendidikan Agama di Indonesia selama ini?

Menarik untuk melihat bagaimana Kurikulum 2013 yang diberlakukan dalam pendidikan di sekolah dasar dan menengah saat ini memiliki perhatian besar terhadap pembentukan karakter kebangsaan bagi para siswa. Penelitian ini tidak akan membahas tentang pro dan kontra yang pernah muncul terkait dengan penerapan Kurikulum 2013, melainkan akan melihat bagaimana materi pendidikan agama yang diberikan kepada para siswa. Dalam Kurikulum 2013 terdapat perubahan nama Pendidikan Agama menjadi Pendidikan Agama dan Budi Pekerti yang diberikan bagi para siswa, sesuai dengan agama yang dianutnya.

Berangkat dari asumsi dan situasi tersebut di atas, penelitian ini secara khusus berusaha melihat bagaimana Pendidikan Agama Islam dan Budi Pekerti (PAI-BP) pada Kurikulum 2013 diberikan untuk mengakomodasi dan memberi pendasaran bagi para siswa tentang pengetahuan agama Islam dan kesadaran sosial mereka melalui materi-materi yang diberikan di sekolah. Dengan demikian ketiga aspek sebagaimana disebut di atas sudah terangkum dalam upaya pencegahan terhadap meningkatnya paham radikalisme di kalangan kaum muda.

Sebagai gambaran umum bahwa para siswa yang saat ini duduk di bangku SD-SMA berusia 6-17 tahun. Itu berarti bahwa mereka lahir setelah tahun 2000-an. Mereka lahir pada era di mana internet sudah sedemikian familiar bagi masyarakat. Maka dilihat dari kurikulum pendidikan di Indonesia, para siswa/i ini sebagian besar mengalami dua kurikulum yang berbeda, yakni Kurikulum Tingkat Satuan Pendidikan (KTSP) yang mulai diber- 
lakukan pada tahun 2006 dan Kurikulum 2013. Diperkirakan bahwa 10-20 tahun ke depan generasi inilah yang akan banyak berkiprah di masyarakat.

Penelitian ini akan menggunakan metode pustaka, yakni dengan membaca dan menganalisa materi-materi yang ada pada buku Pendidikan Agama Islam dan Budi Pekerti sekolah dasar (SD/ MI) dan menengah (SMP/MTs, SMA/MA/SMK/MAK). Buku-buku ini diterbitkan oleh Kementerian Pendidikan dan Kebudayaan RI sebagai bahan ajar Kurikulum 2013. Selain itu sejumlah penelitian lain yang sudah pernah dilakukan akan dimanfaatkan sebagai pendukung dan alat analisis temuan dari kajian ini.

\section{B. Kaum Muda (Muslim) di Tengah Globalisasi}

Di era globalisasi, kaum muda menghadapi bermacam tantangan. Era globalisasi, yang oleh Jalal Al-e Ahmad dipandang seringkali menggerus nilai-nilai budaya setempat, juga berdampak pada kaum muda yang sedang berproses dalam pencarian identitas mereka (Deylami 2011, 251). Berbaurnya beragam budaya dan gaya hidup yang bisa dengan mudah didapatkan dan dilihat, baik dalam kehidupan sehari-hari maupun melalui internet, tak jarang menimbulkan kegamangan identitas bagi sebagian besar kaum muda. Chaider S. Bamualim, et all. menyebut situasi ini sebagai hibriditas identitas (hybridation of identity) yang merupakan sebuah fenomena keagamaan yang sedang dialami oleh kaum muda, yaitu adanya identitas keagamaan sebagai hasil dari persilangan afiliasi dan orientasi keagamaan berdasarkan dinamika sosial-politik keagamaan yang dialami oleh kaum muda (Bamualim et all. 2018, 69).

Hibridasi identitas ini juga terkait erat dengan beragam informasi yang diterima oleh kaum muda. Mudahnya memperoleh informasi keagamaan, baik itu ceramah-ceramah agama maupun tulisan-tulisan yang terkait dengan agama, akan berpengaruh pada cara pandang keagamaan kaum muda. Bermacam informasi itu akan diakomodasi dalam diri kaum muda, dan pada akhirnya diambil sebagai pandangan dan ideologi yang dihidupi. Maka 
akan berbahaya apabila informasi yang diterima itu merupakan informasi yang bersifat radikal.

Martin van Bruinessen memperlihatkan bagaimana gejala radikalisme dan ekstrimisme dalam beragama menguat pasca Orde Baru, yang ia sebut sebagai conservative turn. Menurutnya, pasca mundurnya Presiden Suharto, Islam Indonesia menunjukkan wajah yang berbeda dari "smiling face" menjadi wajah yang garang, di mana selama beberapa tahun muncul konflik-konflik kekerasan antar-agama dan gerakan-gerakan jihad. Selain itu banyak terjadi pula beragam aksi terorisme dengan bermacam kejadian bom di sejumlah gereja saat perayaan Natal tahun 2000 dan bom Bali tahun 2002. Citra negatif terhadap Islam ini semakin diperbesar dengan adanya upaya-upaya sekelompok orang untuk memasukkan kembali rumusan Piagam Jakarta ke dalam Undang-undang (van Bruinessen 2011, 3).

Noorhaidi Hasan mengidentifikasi sejumlah kelompok atau organisasi Islam yang mengangkat isu-isu tersebut, antara lain kelompok paramiliter Muslim yang menempatkan diri mereka sebagai pembela Islam yang terdepan seperti Laskar Pembela Islam, Laskar Jihad, dan Laskar Mujahidin Indonesia. Kelompokkelompok ini sering tampil di ruang public dengan memenuhi jalan-jalan menuntut penerapan syari'ah secara menyeluruh, menggerebek kafe-kafe, diskotik, tempat perjudian, rumah pelacuran, dan sarang-sarang kejahatan lainnya, serta menyerukan jihad di Maluku dan daerah-daerah kacau lain (Hasan 2008, 2).

Ada pula sejumlah kelompok muda yang dibentuk oleh partai-partai politik, organisasi-organisasi massa, dan rezim penguasa, seperti: Barisan Pemuda Ka'bah, Pam Swakarsa, Pendekar Banten, Gerakan Pemuda Islam (GPI), dan Front Hizbullah Bulan Bintang. Mereka bekerjasama dengan organisasiorganisasi Islam konservatif lain, seperti Komite Indonesia untuk Solidaritas Dunia Islam (KISDI), Jamaah Ikhwanul Muslimin Indonesia (JIM), Hizbut Tahrir Indonesia (HTI), Kesatuan Aksi Mahasiswa Muslim Indonesia (KAMMI), dan Himpunan Aksi Mahasiswa Muslim Antar-kampus (Hammas) (Hasan 2008, 3). 
Seiring berkembangnya teknologi komunikasi dan informasi saat ini juga semakin mempermudah pula aktor-aktor penyebar ideologi radikal. Berkedok menyebarkan pesan-pesan agama, baik melalui video-video ceramah maupun tulisan-tulisan keagamaan, seringkali mereka pun menyisipkan pesan-pesan radikal yang dapat memengaruhi kaum muda melalui internet dan media masa.

Penelitian yang dilakukan oleh Center for The Study of Religion and Culture (CSRC) - Pusat Kajian Agama dan Budaya UIN Syarif Hidayatullah Jakarta pada September 2017- Januari 2018 memperlihatkan bahwa kaum muda saat ini, yang dikenal sebagai generasi milenial, lebih banyak belajar agama melalui media sosial dan internet daripada belajar dari lembaga-lembaga keagamaan ataupun ulama. Sebab itu wajar bila media sosial mampu mereduksi peran sekolah maupun keluarga dalam aktivitas mempelajari agama (Bamualim et all. 2018, 26).

Kemudahan internet menjadi alasan mengapa generasi milenial memilih mencari informasi keagamaan melalui ustadzustadz di dunia maya. Mereka juga bisa dengan mudah mencari tema-tema yang hendak dipelajari melalui search engine. Tanpa harus hadir ke pengajian pun, mereka bisa menyimak dari jauh. Demikian juga mereka tak perlu khawatir terlambat karena dapat memutar ulang dari video ceramah yang diinginkannya.

Selain melalui media internet, literatur-literatur keagamaan saat ini juga semakin banyak bersebaran, yang disertai dengan bermacam ideologi. Penelitian mengenai literatur keislaman di kalangan generasi milenial menunjukkan bahwa terdapat bermacam literatur keislaman yang berkembang di kalangan generasi milenial, seperti Jihadi, Tahriri, Salafi, Tarbawi, dan Islamisme populer. Penelitian ini merupakan penelitian gabungan antara Pascasarjana UIN Sunan Kalijaga, Pusat Pengkajian Islam, Demokrasi dan Perdamaian (PusPIDeP) Yogyakarta, Project Management Unit (PMU) CONVEY dan PPIM Jakarta. Dalam penelitian tersebut ditemukan bagaimana ideologi-ideologi tersebut dikemas sedemikian rupa dalam literatur-literatur, baik melalui 
novel, cerita fiksi, serta tema-tema yang menarik di kalangan kaum muda (Hasan 2018, 279).

\section{Quo Vadis Pendidikan Agama di Sekolah?}

Berhadapan dengan situasi di atas, maka muncul pertanyaan: Bagaimana pendidikan agama bagi kaum muda semestinya diarahkan untuk mengantisipasi semakin berkembangnya paham-paham radikal di kalangan kaum muda? Di saat internet dan media sosial telah menjadi alternatif yang banyak dipilih kaum muda untuk belajar agama, bagaimana pendidikan agama semestinya diberikan?

Semestinya pendidikan agama yang secara formal diajarkan di sekolah mampu memberi pendasaran bagi seorang siswa dalam perkembangan pengetahuan agama selanjutnya. Pendidikan agama menjadi sarana untuk memberikan pengetahuan agama yang benar serta menumbuhkan karakter yang baik bagi para siswa. Maka dari itu, pendidikan agama perlu bergerak di dua bidang ini: pengetahuan agama yang benar dan karakter yang baik sebagai seorang beragama. Kedua bidang ini oleh Suhadi, et all. disebut dengan aspek internal (peningkatan iman dan kesalehan) dan eksternal (pengembangan toleransi) (Suhadi et all. 2015, 4).

Hal ini pula yang nampaknya hendak ditekankan oleh Pemerintah melalui Kurikulum Pendidikan 2013. Dalam Kurikulum 2013, nama mata pelajaran agama yang diberikan kepada siswa, dibubuhi dengan tambahan kata "Budi Pekerti." Nama mata pelajaran agama itu sekarang menjadi Pendidikan Agama (Islam/Kristen/Katolik/Budha/Hindu/Khonghucu) dan Budi Pekerti. Muhammad Nuh, Menteri Pendidikan dan Kebudayaan RI menegaskan bahwa penambahan kata "Budi Pekerti" ini merupakan bagian dari upaya penyesuaian terhadap Kurikulum 2013 yang disusun untuk menyempurnakan kurikulum sebelumnya, dengan pendekatan belajar aktif berdasarkan nilai-nilai budaya bangsa (Kemdikbud 2014, iii). Nampaknya perubahan nama ini hendak menempatkan "budi pekerti" sebagai bagian integral dari 
pendidikan agama.

Jauh sebelum Kurikulum 2013 diberlakukan, Pasal 3 Undang-Undang No 20 tahun 2003 tentang Sistem Pendidikan Nasional telah menegaskan tujuan dari pendidikan yakni "untuk mengembangkan potensi peserta didik agar menjadi manusia yang beriman dan bertakwa kepada Tuhan Yang Maha Esa, berakhlak mulia, sehat, berilmu, cakap, kreatif, mandiri, dan menjadi warga negara yang demokratis dan bertanggungjawab." Dari tujuan tersebut, sebenarnya sudah ada upaya untuk menjadikan pendidikan sebagai sarana pembentukan karakter bagi setiap peserta didik, yang diimplementasikan melalui kebijakan kurikulum yang diberlakukan oleh pemerintah melalui Kementerian Pendidikan dan Kebudayaan.

Nampaknya penambahan istilah "Budi Pekerti" ini memang cukup beralasan. Penanaman nilai-nilai "budi pekerti" sendiri merupakan hal yang mendesak diberikan sejak dini. Ensiklopedi Pendidikan mendefinisikan character (budi pekerti) sebagai "the attitudes and behaviours of an individual's daily life, of families, communities and nations that contains values applied and adopted in the form of identity, unity and integrity, and future sustainability in a moral system, and guides human behaviour" (Suhadi et all. 2015, 49). Definisi ini menunjukkan bagaimana karakter atau budi pekerti itu menjadi hal mendasar yang perlu ditanamkan.

Driyarkara (1913-1967), salah seorang tokoh pendidikan dan filsuf di Indonesia, menjelaskan bahwa pendidikan merupakan proses hominisasi dan humanisasi (Sudiarja SJ et all. 2006, 371). Proses hominisasi merupakan proses penjadian manusia yang sederhana, sementara itu proses humanisasi adalah perkembangan yang lebih sempurna di mana manusia menjadi pribadi yang berbudaya. Pemikiran ini dilatarbelakangi oleh sejumlah tokoh eksistensialisme seperti Maurice MerleauPonty, E. Le Roy dan Martin Heidegger, yang memandang tentang bagaimana manusia berada. Dalam filsafat eksistensialisme ini, ada dua pendapat klasik mengenai cara berada manusia. Pertama, manusia dianggap hanya sebagai hasil (resultat) dari daya-daya 
fisik, fisiologis, dan sosiologis, yang menentukannya dari luar dan yang menyebabkan dia berada sebagai benda di antara bendabenda lain. Dan yang kedua, manusia sebagai subyek dengan cara yang sedemikian rupa sehingga yang ada hanya subyek (Sudiarja SJ et all. 2006, 272-274).

Dalam hal ini, Driyarkara menjelaskan bahwa sebagai proses hominisasi dan humanisasi, pendidikan semestinya bergerak di dua bidang sekaligus, yakni memanusiakan diri dan sesamanya. Pendidikan semestinya mengarahkan seseorang untuk sadar bahwa keberadaannya sebagai manusia akan semakin penuh ketika ia ada bersama dengan yang lain dengan saling membangun (Sudiarja SJ et all. 2006, 278). Melalui pendidikan inilah interaksi antar subyek itu terjadi sehingga muncul pribadi-pribadi yang utuh.

Kesadaran ada bersama inilah yang perlu semakin ditekankan melalui pendidikan. Dalam konteks pendidikan agama, siswa perlu diberi pendasaran yang kuat untuk membangun kesadaran tentang keberadaannya sebagai umat beragama yang berinteraksi atau ada bersama dengan umat beragama lain. Melalui pendidikan agama, siswa dibimbing untuk menyadari keberadaannya di tengah masyarakat yang berbeda-beda. Nilainilai toleransi menjadi salah satu poin yang perlu dimasukkan sebagai bagian dari "budi pekerti" yang diberikan pada para siswa.

Bila dilihat secara umum, Kurikulum 2013 nampaknya memang hendak memberi perhatian serius tentang penanaman karakter ini, tidak hanya dalam pelajaran agama tetapi di setiap pelajaran. Kurikulum 2013 berupaya semakin meningkatkan kompetensi siswa, baik itu dalam hal sikap, keterampilan, dan pengetahuan yang secara khusus diatur dalam Peraturan Menteri Pendidikan dan Kebudayaan No. 54 Tahun 2013 tentang Standar Kompetensi Lulusan Pendidikan Dasar dan Menengah. Penyusunan materi dalam buku-buku Pendidikan Agama Islam dan Budi Pekerti di semua tingkat pendidikan (SD, SMP, SMA/SMK dan sederajatnya), misalnya, dilakukan untuk memenuhi Kompe- 
Pendidikan Agama Islam dan Budi Pekerti yang Inklusif dan Toleran

tensi Inti dan Kompetensi Dasar. Kompetensi Inti adalah tingkat kemampuan untuk mencapai standar kompetensi lulusan yang harus dimiliki seorang peserta didik pada setiap tingkat kelas. Sementara itu, Kompetensi Dasar merupakan kemampuan dan materi pembelajaran minimal yang harus dicapai peserta didik untuk suatu mata pelajaran pada masing-masing satuan pendidikan yang mengacu pada kompetensi inti.

Peraturan Menteri Pendidikan dan Kebudayaan RI No. 24 Tahun 2016 tentang Kompetensi Inti dan Kompetensi Dasar Pelajaran pada Kurikulum 2013 pada Pendidikan Dasar dan Pendidikan Menengah pasal 2 ayat 3 menjelaskan dan menguraikan kedua hal ini. Kompetensi Inti dibagi dalam empat kompetensi, yaitu: Kompetensi Inti 1 (Sikap Spiritual), Kompetensi Inti 2 (Sikap Sosial), Kompetensi Inti 3 (Pengetahuan) dan Kompetensi Inti 4 (Keterampilan). Dari keempat kompetensi tersebut, materi-materi pelajaran disusun sedemikian rupa sehingga mampu memenuhi tujuan dari pembelajaran, yang secara khusus dijabarkan dengan mengacu pada Kompetensi Dasar.

Baik Kompetensi Inti maupun Kompetensi Dasar tersebut memperlihatkan bagaimana Kurikulum 2013 berusaha untuk menjadikan pendidikan sebagai tempat pembentukan pribadi yang utuh, baik dalam hal pengetahuan, kepribadian dan sosial. Dalam hal ini, pendidikan menjadi proses pembentukan manusia secara utuh, atau dalam pemikiran Driyarkara "proses manusia memanusiakan diri dan sesama." Secara khusus pada Kompetensi Inti 2 (Sikap Sosial) menunjukkan bagaimana pendidikan disadari sebagai tempat untuk menjadikan siswa mampu berinteraksi dalam hubungannya dengan sesama dan makhluk ciptaan lain.

\section{Materi PAI-BP Kurikulum 2013: Inklusif dan Toleran}

Sejumlah isu yang mengemuka di masyarakat seputar radikalisme atau konservatisme umumnya berkaitan dengan isu-isu politik yang pada akhirnya terkait pula dengan agama lain, antara lain: jihad, khilafah Islam, salafisme, kepemimpinan publik, boleh 
tidaknya mengucapkan selamat hari raya pada penganut agama lain.

Azyumardi Azra membuat tiga parameter dan indikator dari gejala "radikalisme" yang terjadi. Pertama, adanya paham dan ideologi transnasional yang bertujuan membangun negara Islam (dawlah Islamiyah) atau kekhalifahan (khilafah) untuk menggantikan NKRI, Pancasila, dan Bhineka Tunggal Ika. Bagi pendukung ideologi radikal, dawlah Islamiyah atau khilafah adalah sistem politik untuk menyelesaikan masalah politik, ekonomi, dan sosial-budaya. Kedua, adanya sikap takfiri, mengafirkan mereka yang seagama, tetapi berbeda paham dan praksis keagamaan. Sikap takfiri yang mencerminkan intoleransi dan permusuhan terbuka tertuju pada aliran dan mazhab lain semacam Ahmadiyah dan Syiah. Ketiga, adanya pengharaman sikap toleran dan bermuamalah secara baik (mujamalah) dengan penganut agama lain. Bagi mereka, penganut agama lain adalah penghalang penerapan Islam secara sempurna (kaffah) (Azra 2018, 1).

Isu-isu yang beredar di masyarakat tersebut mengarahkan kita untuk memikirkan ajaran doktrinal apa saja yang bisa mendasari para siswa untuk memahami dan mendalami ajaran agamanya secara benar di satu sisi (aspek internal), dan sekaligus menjadi pribadi yang terbuka terhadap orang lain (aspek eksternal). Dengan kata lain, Pendidikan Agama (Islam) dan Budi Pekerti semestinya mampu mengarahkan para siswa untuk menjadi pribadi-pribadi yang inklusif dan toleran.

Penelitian terhadap materi Pendidikan Agama Islam dan Budi Pekerti untuk SD, SMP dan SMA menunjukkan bagaimana Pemerintah melalui Kemendikbud berusaha memberikan pendidikan agama dan karakter bagi siswa secara seimbang. Dalam aspek pengetahuan keagamaan Islam (internal), materi yang disajikan dapat dirangkum dalam beberapa segi: Rukun Iman, Rukun Islam, sejarah Islam, dasar-dasar Bahasa Arab. Disajikan pula kisah-kisah teladan para Nabi dan tokoh-tokoh besar Islam, termasuk pula Walisongo (Kelas 4 Pelajaran 10). Materi-materi tentang Rukun Iman, Rukun Islam dan dasar-dasar Bahasa Arab 
diberikan secara terpisah-pisah satu sama lain di setiap tingkat kelas. Kutipan-kutipan Al-Qur'an sebagai bahan pelajaran dipilih secara tematik, dan dalam beberapa kasus dipilih Surah-surah yang pendek sebagai bahan pembelajaran Bahasa Arab.

Berhadapan dengan situasi saat ini, di mana isu-isu di seputar penerapan kembali Syariat Islam didengungkan beberapa kelompok yang seringkali tampil dengan "wajah garang", pada Pelajaran 5 Kelas 9 dijelaskan tentang bagaimana kehadiran Islam sendiri di Nusantara. Berikut kutipan dari materi tersebut:

"Demikian pula yang dilakukan oleh para penyebar Islam di Nusantara, mereka berdakwah dengan penuh semangat dan keikhlasan. Samudera luas bukan penghalang untuk berdakwah, justru sebaliknya menjadi pemacu semangat. Sambil berdagang para penyebar Islam tersebut datang ke Nusantara untuk berdakwah. Kedatangan mereka disambut hangat dan diterima dengan baik. Hal ini disebabkan dakwah yang mereka lakukan adalah dakwah dengan cara-cara damai, bukan dengan kekerasan. Bagi Islam, tidak ada paksaan dalam beragama karena telah tampak jelas mana yang haq dan batil." (Kemdikbud 2015, 94).

Poin tentang cara dakwah yang damai dan dilakukan tanpa kekerasan ini ditekankan kembali dalam bagian Refleksi Akhlak Mulia di bab yang sama. Siswa diajak untuk merefleksikan demikian: "Para ulama penyebar Islam di Nusantara melakukan dakwah dengan cara damai dan jauh dari paksaan atau kekerasan. Sebagai generasi penerus, hal ini patut untuk saya teladani" (hal. 115). Menurut penulis, hal ini merupakan sebuah upaya yang pantas ditekankan secara khusus bagi para siswa dalam menumbuhkan semangat damai. Poin yang sama ditegaskan kembali pada materi Bab 4 Kelas 11 (Kemdikbud 2014, 60).

Kaitan antara Islam dan Peradaban juga dibahas dalam beberapa bab, khususnya menyangkut ilmu pengetahuan. Salah satu bab yang membahas yakni materi Bab 5 "Masa Kejayaan Islam yang Dinantikan Kembali" Kelas 11. Dalam bab ini dibicarakan bagaimana Islam berperan besar dalam kemajuan 
peradaban dunia melalui tokoh-tokoh intelektual Islam, seperti Ibn Rusyd, Al-Gazali, Al-Kindi, Al-Farabi, Ibnu Sina. Mereka merupakan intelektual-intelektual Islam yang turut berperan besar dalam memajukan peradaban Islam dan dunia. Ditekankan dalam materi ini bagaimana ilmu pengetahuan merupakan hal mendasar dalam membangun peradaban.

Satu hal menarik dalam materi tersebut yakni ajakan untuk membangkitkan kembali semangat para tokoh tersebut melalui budaya literasi. "Perpustakaan sekolah sebagai jantung peradaban tidak banyak dikunjungi karena terlena dengan mainan baru berupa alat komunikasi, seperti handphone. Bukankah Islam jaya karena keingintahuan akan ilmu pengetahuan begitu besar yang diwujudkan dengan transliterasi buku-buku berkualitas dan dijadikannya rujukan untuk mengembangkan ilmu pengetahuan yang terus berkembang?" (Kemdikbud 2014, 71).

Isu tentang jihad dibicarakan dalam kaitannya dengan gerakan pembaruan Islam di masa modern. Materi ini diberikan pada Bab 10 Kelas 11, yakni pada materi "Bangun dan Bangkitlah Wahai Pejuang Islam" (hal. 164). Pada materi ini dipaparkan sejumlah tokoh pembaharu Islam di masa modern, yakni Muhammad bin Abdul Wahab, Syah Waliyullah, Muhammad Ali Pasya, Al-Tahtawi, Jamaludin Al-Afghani, Muhammad Abduh, Rasyid Rida, Sayyid Ahmad Khan, dan Sultan Mahmud II. Gerakan pembaruan yang dilakukan oleh Muhammad bin Abdul Wahab melalui Wahabismenya merupakan isu yang relevan di Indonesia. Pandangan dan gerakan pembaruannya mengambil sikap keras dalam mendefinisikan siapa yang bisa dianggap beriman, dengan mensyaratkan bahwa tidak boleh ada penyimpangan terhadap syariah, dan membedakan secara ketat antara dunia dunia orang beriman dan mereka yang tidak beriman (Noorhaidi Hasan 2008, 33). Karena itu banyak kelompok yang memunculkan sikap anti terhadap gerakan ini. Maka dalam menjelaskan materi ini, para guru mesti bersikap hati-hati sehingga tidak menimbulkan kesalahpahaman bagi siswa. Bagian refleksi yang perlu penjelasan lebih lanjut yakni ajakan untuk memahami jihad yang sesuai dengan al-Qur'an dan hadis (Kemdikbud 2014, 179). Sayang, 
pada bagian tersebut tidak diberi penjelasan lebih lanjut.

Mengenai dasar-dasar pemerintahan demokrasi, diberikan materi Kelas 12 Bab 4 "Bersatu dalam Keragaman Demokrasi". Di tengah isu-isu tentang penegakan Syariat Islam yang diusung oleh beberapa kelompok, menarik untuk mencermati materi ini di mana di dalamnya diungkapkan tentang bagaimana persamaan hak sebagai warga negara sangat dijunjung tinggi dalam Islam. Demikian juga ditegaskan bahwa nilai-nilai demokrasi sebenarnya sangat sejalan dengan nilai-nilai Islami sendiri. "Demokrasi memang istilah yang lahir dari dunia Barat, tetapi jangan pernah lupa, Islam bersikap akomodatif terhadap semua yang datang dari luar, Barat atau Timur, jika nilai-nilai yang diusungnya sejalan dengan nilai-nilai Islam sendiri, maka itu berarti Islami." (Kemdikbud 2015, 58). Penjelasan mengenai demokrasi juga disertai dengan dalil-dalil Al-Qur'an dan hadis serta pendapatpendapat ulama yang berbeda-beda.

Mengenai nilai-nilai budi pekerti, sejumlah tema yang diberikan antara lain: perilaku menghormati orang lain, kejujuran, ketekunan, kasih sayang, dan toleransi. Secara khusus mengenai penanaman nilai-nilai toleransi, ada beberapa bab yang secara langsung memberikan pengetahuan tentang perbedaan agama di masyarakat. Pada materi PAI-BP Kelas VI Pelajaran I dengan judul "Indahnya Saling Menghormati". Materi pada bagian ini diawali dengan memperlihatkan lambang Negara Indonesia, yakni Garuda Pancasila dan semboyan Bhineka Tunggal Ika (Kemdikbud 2015, 1). Melalui lambang dan semboyan tersebut para siswa hendak disadarkan bahwa meskipun ada perbedaan suku dan agama (keyakinan), namun saling menghormati.

Pada bagian selanjutnya dipaparkan gambar tentang aneka agama di Indonesia beserta tempat ibadahnya masing-masing. Masing-masing diberi keterangan singkat: "Umat Islam menuju Masjid", "Umat Kristen/Katolik menuju Gereja", "Umat Hindu menuju Pura", "Umat Buddha menuju Wihara”, dan "Umat Khonghucu menuju Kelenteng". Dari gambar tersebut, para siswa diajak untuk mengamati dan menceritakan pemahamannya atas 
gambar tersebut.

Pada materi ini, siswa diajak untuk membaca, mengenal dan memahami Surat al-Kafirun. "Surat al-Kafirun adalah surat ke-109. Jumlah ayat surat al-Kafirun 6 (enam) ayat. Surat alKafirun mengisyaratkan tentang pupusnya harapan orang-orang kafir Qurays Mekah zaman itu tehadap dakwah nabi Muhammad saw.. Nabi Muhammad saw. tidak mau mengikuti tata cara beribadah orang-orang kafir Quraisy, mereka dipersilahkan beribadah menurut ajaran agamanya sendiri. Surat al-Kafirun tergolong surat Makkiyah, karena diturunkan di kota Mekah sesudah surat al-Ma'un. Dinamai "al-Kafirun" (orang-orang kafir) diambil dari perkataan "al-Kafirun" yang terdapat pada ayat pertama surat ini." (Kemdikbud 2015, 3).

Surat al-Kafirun tersebut menegaskan tentang sikap menghormati orang yang beragama lain dapat dilakukan dengan cara meneladan Nabi Muhammad saw. Nabi Muhammad saw. tidak mau mengikuti tata cara ibadah orang lain (yang dalam Surat alKafirun disebut sebagai "orang-orang kafir" pada zamannya) dan mempersilahkan orang-orang kafir beribadah sesuai tata caranya sendiri, dan kaum Muslim melakukannya dengan tata caranya sendiri. Dari materi pada Pelajaran 1 PAI-BP Kelas 6 tersebut, nilai toleransi dipahami sebagai sikap menghormati tata cara ibadah masing-masing agama. Semangat toleransi nampak dalam sikap yang ditunjukkan dalam Surat al-Kafirun ayat 6: "Untukmu agamamu, dan untukku agamaku."

Materi toleransi juga diberikan dalam Bab 8 PAI-BP Kelas 9 dengan judul bab "Damaikan Negeri dengan Toleransi" (Kemdikbud 2015, 165). Dalam bab ini, makna toleransi (tasamuh) dijelaskan sebagai sikap menghargai dan menghormati perbedaan antarsesama manusia. Alasan mendasar yakni Allah Swt. menciptakan manusia berbeda satu sama lain (hal. 170). Dalam bab ini para siswa juga diajak untuk menyadari bahwa ada begitu banyak perbedaan (suku, ras, agama) di Indonesia. Maka dalam menyikapi aneka perbedaan itu dibutuhkan sikap toleransi, dengan cara saling menghormati dan menghargai satu sama lain. 
Bab 12 PAI-BP Kelas 9 juga mengangkat tema tentang toleransi: "Menyuburkan Kebersamaan dengan Toleransi dan Menghargai Perbedaan" (Kemdikbud 2015, 253). Pada bab ini para siswa diajak untuk menyadari pentingnya memiliki sikap toleransi. Selain itu, diajarkan pula landasan dasar perlunya toleransi menurut agama Islam. Dalam hal ini para siswa diajak untuk memaknai QS Al-Hujurat/49:13: "Wahai manusia! Sungguh, Kami telah menciptakan kamu dari seorang laki-laki dan seorang perempuan, kemudian Kami jadikan kamu berbangsa-bangsa dan bersuku-suku agar kamu saling mengenal. Sesungguhnya yang paling mulia di antara kamu di sisi Allah ialah orang yang paling bertakwa. Sungguh, Allah Maha Mengetahui, Mahateliti."

Materi tentang toleransi ini semakin diperkaya di Kelas 11. Pada Bab 11 "Toleransi sebagai Alat Pemersatu Bangsa” (Kemdikbud 2014, 184), para siswa diajak untuk semakin menyadari pentingnya memiliki perilaku toleransi di tengah masyarakat. Siswa diajak untuk melibatkan diri dalam upaya menjaga persatuan dan kesatuan NKRI.

Berikut ini tiga perilaku toleransi yang harus dibina dan dimiliki oleh setiap orang sesuai dengan ajaran Islam, sebagaimana dipaparkan dalam bab tersebut (Kemdikbud 2014, 195-196):

1) Saling menghargai adanya perbedaan keyakinan. Kita tidak boleh memaksakan kehendak kepada orang lain agar mereka mengikuti keyakinan kita. Orang yang berkeyakinan lain pun tidak boleh memaksakan keyakinan kepada kita. Dengan memperlihatkan perilaku berakhlak mulia, insya Allah orang lain akan tertarik. Rasulullah saw. selalu memperlihatkan akhlak mulia kepada siapa pun termasuk musuh-musuhnya, banyak orang kafir yang tertarik kepada akhlak Rasulullah saw. lalu masuk Islam karena kemuliaannya.

2) Saling menghargai adanya perbedaan pendapat. Manusia diciptakan dengan membawa perbedaan. Kita mencoba menghargai perbedaan tersebut.

3) Belajar empati, yaitu merasakan apa yang dirasakan oleh orang lain, lalu bantulah orang yang membutuhkan. Sering 
terjadi tindak kekerasan disebabkan hilangnya rasa empati. Ketika mau mengganggu orang lain, harus sadar bahwa mengganggu itu akan menyakitkan, bagaimana kalau itu terjadi pada diri kita.

Ketiga perilaku toleran tersebut terangkum dalam definisi toleransi yang diberikan oleh UNESCO (United Nations Educational, Scientific and Cultural Organization) yang mendefinisikan toleransi dalam 3 aspek: 1) sikap respek (menghormati), 2) penerimaan, dan 3) apresiasi. UNESCO dalam Declaration of Principles on Tolerance yang dikeluarkan pada 1995 artikel 1 no 1.1 mengartikan toleransi sebagai berikut:

Tolerance is respect, acceptance and appreciation of the rich diversity of our world's cultures, our forms of expression and ways of being human. It is fostered by knowledge, openness, communication, and freedom of thought, conscience and belief. Tolerance is harmony in difference. It is not only a moral duty, it is also a political and legal requirement. Tolerance, the virtue that makes peace possible, contributes to the replacement of the culture of war by a culture of peace.

Ada beberapa bagian lain yang menyinggung tentang nilainilai toleransi. Misalnya, pada Bab 12 PAI-BP Kelas 7 dikisahkan tentang sikap Nabi Muhammad saw. terhadap umat non-Muslim di Madinah. Dikisahkan bahwa ketika Nabi Muhammad saw. diangkat menjadi pemimpin di Madinah, beliau membuat suatu piagam yang berlaku bagi seluruh kaum muslimin dan orangorang non-muslim di Madinah. Pada masa itu, Nabi Muhammad saw. berusaha agar kehidupan bersaudara terus terjaga, di mana Madinah saat itu ditempati bukan hanya oleh umat Islam, tetapi juga ada umat non-Muslim. Maka Nabi Muhammad saw. membuat suatu kesepakatan bersama agar terjadi hubungan yang harmonis, saling menghormati, toleransi, dan menjaga lingkungan di Madinah. Piagam inilah yang oleh Ibnu Hisyam disebut sebagai undang-undang dasar negara dan pemerintahan Islam yang pertama. Isinya mencakup, antara lain, perikemanusiaan, keadilan sosial, toleransi beragama, dan gotong royong (Kemdik- 
bud 2013, 145-146). Gambaran kehidupan yang diwarnai dengan sikap toleransi pada masa Nabi Muhammad saw. di Madinah dapat menjadi sumber inspirasi bagi para siswa untuk memiliki semangat yang sama pula.

Selain itu, pengetahuan tentang agama lain sedikit disinggung dalam materi Bab 1 Kelas 8 "Meyakini Kitab-Kitab Allah, Mencintai Al-Qur'an". Dijelaskan tentang kitab-kitab yang diwahyukan sebelum Al-Qur'an: Taurat, Zabur, Injil beserta komunitas umat beriman yang menerima kitab-kitab tersebut. Terhadap komunitas umat beriman yang menerima kitab-kitab tersebut, para siswa diajak untuk memiliki sikap mulia "toleran dan menghargai pemeluk agama lain" (Kemdikbud 2014, 1) meskipun tidak dijelaskan lebih lanjut tentang sikap ini.

Penelitian terhadap materi-materi PAI-BP Kurikulum 2013 menunjukkan bagaimana pemerintah dengan serius hendak memberikan perhatian terhadap pendidikan agama bagi para siswa sejak dini. Dan nampak bahwa materi-materi yang diberikan relative bernuansa inklusif.

\section{E. Penutup}

Salah satu tujuan diterbitkannya Buku Pendidikan Agama Islam dan Budi Pekerti Kurikulum 2013 adalah untuk memberikan yang terbaik bagi kemajuan dunia pendidikan dalam rangka mempersiapkan generasi seratus tahun Indonesia Merdeka (2045). Hal inilah yang disampaikan oleh Menteri Pendidikan dan Kebudayaan dalam Kata Pengantar buku PAI-BP di setiap kelas. Nampak bahwa situasi keagamaan yang terjadi beberapa tahun terakhir ini menjadi salah satu perhatian serius oleh pemerintah dalam mempersiapkan materi ajar bagi siswa, terlebih dalam upaya menanggapi isu-isu intoleransi.

Penelitian terhadap materi dalam buku PAI-BP menunjukkan bahwa pemerintah hendak memberikan materi yang bersifat inklusif secara seimbang kepada para siswa, mengenai pengetahuan dan sikap keagamaan yang sesuai dengan situasi kehidupan bangsa Indonesia. Sebagai umat beragama, melalui 
materi-materi yang ada, para siswa diajak untuk menyadari bahwa ia ada bersama dengan orang lain serta dalam realitas masyarakat plural atau majemuk.

Meskipun materi-materi yang disiapkan oleh pemerintah telah memperlihatkan sikap yang inklusif dan toleran, namun perlu diperhatikan pula bagaimana guru dan orangtua turut mendukung penanaman nilai-nilai tersebut. Materi yang dipersiapkan hanyalah sarana pendukung. Maka guru agama dan orangtua turut berperan besar dalam upaya memberikan pemahaman yang tepat mengenai nilai-nilai tersebut. Dalam buku PAI-BP ini diberikan kolom khusus pada setiap bab mengenai peran orangtua yang turut mengawasi perkembangan anakanaknya. Dan ini merupakan kesempatan bagi orangtua untuk berpartisipasi dalam pendidikan anak-anaknya. Perlu disadari pula bahwa tidak semua sekolah memakai buku PAI-BP yang dipersiapkan pemerintah ini. Ada banyak buku pendidikan agama yang diterbitkan oleh bermacam penerbit lain. Maka sekolah juga perlu selektif dalam memilih dan memilah buku pegangan yang dipakai sebagai bahan pendidikan agama.

Sebagai catatan terakhir, dalam upaya penanaman nilai inklusif dan toleran dalam beragama, akan sangat baik apabila ditambahkan kesempatan untuk mengalami perjumpaan langsung dengan siswa beragama lain yang diakomodasi oleh guru agama maupun sekolah. Para guru agama bisa melakukan kegiatan bersama dalam konteks pembelajaran agama, misalnya melalui kunjungan ke tempat-tempat ibadah yang ada. Dengan demikian hal ini akan semakin memperkaya wawasan dan pengalaman para siswa melalui perjumpaan mereka dengan teman-teman yang beragama lain. 
Pendidikan Agama Islam dan Budi Pekerti yang Inklusif dan Toleran

\section{DAFTAR PUSTAKA}

Azra, Azyumardi. 2018. "Melindungi Kampus". Kompas.

Bamualim, Chaider S. et all. (eds.). 2018. Kaum Muda Muslim Milenial: Konservatisme, Hibridasi Identitas, dan Tantangan Radikalisme. Jakarta: CSRC UIN Syarif Hidayatullaha.

van Bruinessen, Martin. 2011. "What Happened to the Smiling Face of Indonesian Islam? Muslim Intellectualism and the Conservative Turn in Post-Suharto Indonesia". RSIS Working Paper No. 222. Singapore: S. Rajaratnam School of International Studies (6 Januari 2011).

Deylami, Shirin S. 2011. "In the Face of the Machine: Westoxification, Cultural Globalization, and the Making of an Alternative Global Modernity". Polity 43 (2): 242-263.

Hasan, Noorhaidi. 2008. Laskar Jihad: Islam, Militansi, dan

Pencarian Identitas di Indonesia Pasca-Orde Baru. Jakarta: Pustaka LP3ES Indonesia \& KITLV.

Hasan, Noorhaidi. (Ed.). 2018. Literatur Keislaman Generasi Milenial: Transmisi, Apropriasi, dan Kontestasi. Yogyakarta: Pascasarjana UIN Sunan Kalijaga Press.

Kementerian Pendidikan dan Kebudayaan. 2013. Pendidikan Agama Islam dan Budi Pekerti untuk SMP/MTs Kelas VII. Buku

Siswa. Jakarta: Kementerian Pendidikan dan Kebudayaan.

Kementerian Pendidikan dan Kebudayaan. 2014. Pendidikan Agama Islam dan Budi Pekerti untuk SD/MI Kelas I. Buku Siswa. Edisi Revisi. Jakarta: Kementerian Pendidikan dan Kebudayaan.

Kementerian Pendidikan dan Kebudayaan. 2014. Pendidikan Agama Islam dan Budi Pekerti untuk SD/MI Kelas II. Buku Siswa. Jakarta: Kementerian Pendidikan dan Kebudayaan.

Kementerian Pendidikan dan Kebudayaan. 2014. Pendidikan Agama Islam dan Budi Pekerti untuk SMP/MTs Kelas VIII. Buku Siswa. Jakarta: Kementerian Pendidikan dan Kebudayaan.

Kementerian Pendidikan dan Kebudayaan. 2014. Pendidikan Agama Islam dan Budi Pekerti untuk SD/MI Kelas IV. Buku 
Siswa. Edisi Revisi. Jakarta: Kementerian Pendidikan dan Kebudayaan.

Kementerian Pendidikan dan Kebudayaan. 2014. Pendidikan Agama Islam dan Budi Pekerti untuk SD/MI Kelas V. Buku Siswa. Jakarta: Kementerian Pendidikan dan Kebudayaan.

Kementerian Pendidikan dan Kebudayaan. 2014. Pendidikan Agama Islam dan Budi Pekerti untuk SMA/MA/SMK/MAK Kelas X. Buku Siswa. Jakarta: Kementerian Pendidikan dan Kebudayaan.

Kementerian Pendidikan dan Kebudayaan. 2014. Pendidikan Agama Islam dan Budi Pekerti untuk SMA/MA/SMK/MAK Kelas XI. Buku Siswa. Jakarta: Kementerian Pendidikan dan Kebudayaan.

Kementerian Pendidikan dan Kebudayaan. 2015. Pendidikan Agama Islam dan Budi Pekerti untuk SD/MI Kelas III. Buku Siswa. Jakarta: Kementerian Pendidikan dan Kebudayaan.

Kementerian Pendidikan dan Kebudayaan. 2015. Pendidikan Agama Islam dan Budi Pekerti untuk SD/MI Kelas VI. Buku Siswa. Jakarta: Kementerian Pendidikan dan Kebudayaan.

Kementerian Pendidikan dan Kebudayaan. 2015. Pendidikan Agama Islam dan Budi Pekerti untuk SMP/MTs Kelas IX. Buku Siswa. Jakarta: Kementerian Pendidikan dan Kebudayaan.

Kementerian Pendidikan dan Kebudayaan. 2015. Pendidikan Agama Islam dan Budi Pekerti untuk SMA/MA/SMK/MAK Kelas XII. Buku Siswa. Jakarta: Kementerian Pendidikan dan Kebudayaan.

Peraturan Menteri Pendidikan dan Kebudayaan No. 54 Tahun 2013 tentang Standar Kompetensi Lulusan Pendidikan Dasar dan Menengah.

Peraturan Menteri Pendidikan dan Kebudayaan RI No. 24 Tahun 2016 tentang Kompetensi Inti dan Kompetensi Dasar Pelajaran pada Kurikulum 2013 pada Pendidikan Dasar dan Pendidikan Menengah.

Peraturan Pemerintah Republik Indonesia No. 32 Tahun 2013 
Pendidikan Agama Islam dan Budi Pekerti yang Inklusif dan Toleran tentang Perubahan atas Peraturan Pemerintah No. 19 Tahun 2005 tentang Standar Nasional Pendidikan.

Suhadi, et all. 2015. The Politics of Religious Education: the 2013 Curriculum, and the Public Space of the School. Yogyakarta: CRCS.

Sudiarja, SJ., A. et all. (eds.). 2006. Karya Lengkap Driyarkara: Esaiesai Filsafat Pemikir yang Terlibat Penuh dalam Perjuangan Bangsanya. Jakarta: Gramedia Pustaka Utama.

Tholkhah, Imam. 2009. "Urgensi Pengembangan Pendidikan Agama Islam di Sekolah." In Mereka Bicara Pendidikan Islam: Sebuah Bunga Rampai. Edited by Marwan Saridjo Jakarta: DPP GUPPI dan RajaGrafindo Persada.

UU No. 20 Tahun 2003 tentang Sistem Pendidikan Nasional. 